\title{
Industry and Strategic Analysis of Lamno Robusta Coffee; An Aplication of Multy Criteria Decision Analysis (MCDA) Techniques to Analyze A Small Scale Farming Group
}

\author{
Muhammad Adam ${ }^{1}$, Fathurrahman Anwar ${ }^{2}$ \\ ${ }^{1,2}$ Management Department, Faculty of Economics and Business, Syiah Kuala University, Banda \\ Aceh, Indonesia \\ \{muhammadadam@unsyiah.ac.id $\}$
}

\begin{abstract}
According to the United States Department of Agriculture (USDA), the world coffee consumption is projected to reach 9.792 .000 ton in 2018. Indonesia as one of the largest coffee producers is predicted by USDA to produce 666.000 ton of coffee in 2018. Among many areas that produce coffee in Indonesia, Aceh Jaya District that is famous with its Lamno Robusta Coffee contribute to $0,02 \%$ of the total national coffee production. Regardless its small share in the national coffee market, Lamno Robusta coffee has played a key role in the local market for the last 70 years. This research will apply descriptive qualitative approach to uncover the strategic positioning of Lamno Robusta Coffee. Three multy criteria decision analysis techniques such as Porter's Five Forces Analysis, SWOT Analysis and GE/ McKinsey Matrix will be applied subsequently to analyze the internal and external factors as well as the the industry and business attractiveness of Lamno Robusta Coffee.The reaseach will used both primary and secondary data. The primary data will be collected from direct observation in field, interviews and FGD with the stakeholders. While the secondary data will be get from other the credible resources. The research shows that Lamno Robusta Coffeeis not vulnerable to the bargaining power of buyers, bargaining power of suppliers, and threat of substitution products. However, the threat of the new entrants will play a key role in the increase of potential competition among the existing players in the industry. Concerning to the internal and external factors as well as the business and the industry atractiveness, the Lamno Robusta Coffee is considered in medium position. The results enable stakeholders to formulate strategy to increase the value for the farmers and consumers of Lamno Robusta Coffee..
\end{abstract}

Keywords: Coffee, MCDA, Porter's Five Forces Analysis, SWOT Analysis, GE/McKinsey Matrix

\section{Introduction}

According to the United States Department of Agriculture [1], the amount of coffee consumption in 2018 is projected to be 9.792 .000 ton with the quantity of production approximately 10.272 .000 ton. The data from the International Coffee Organization (ICO) shows that the growth average of coffee consumption was $1,3 \%$ for the last five years. Moreover ICO stated that the emerging market country will be the driver of the world coffee demand [2].

USDA predicted that the total amount of Indonesia coffee production will increase as much as 3000 tons so that the total amount of coffee production will be 666.000 tons in 2018.Consequently, the total export of coffee from Indonesia will increase to reach the amount of 432.000 in 2018 that counted for [1]. It is counted for $64,86 \%$ of the total amount of Indonesia coffee production in 2018. Moreover, the average growth of coffee consumtion in Indonesia was $12,15 \%$ for the last 7 years. While at the same periode of time the growth of Indonesia coffee production only $1,32 \%$. As a result to keep its position as one of the largest coffee exporters and to fullfill the domestic consumption at the same time, Indonesia need to increase its coffee production.Below is the table that shows the data of coffee production and consumption in Indonesia: 
Table 1. Total Coffee Production and Consumption in Indonesia 2010-2018 (in tons)

\begin{tabular}{lrrrrrrrr} 
Year & $2010 / 2011$ & $2011 / 2012$ & $2012 / 2013$ & $2013 / 2014$ & $2014 / 2015$ & $2015 / 2016$ & $2016 / 2017$ & $2017 / 2018$ \\
\hline Robusta Coffee Production & 477.000 & 420.000 & 594.000 & 600.000 & 552.000 & 636.000 & 558.000 & 564.000 \\
\hline Arabica Coffee Production & 82.500 & 78.000 & 120.000 & 114.000 & 76.200 & 90.000 & 78.000 & 72.000 \\
\hline Total Coffee Production & 559.500 & 498.000 & 720.000 & 666.000 & 712.200 & 648.000 & 642.000 & 642.0000 \\
\hline Total Domestic Coffee Consumption & 101.400 & 142.800 & 168.900 & 152.400 & 174.000 & 190.500 & 192.180 & 213.600 \\
Resources: USDA 2010-2018 & & & & & &
\end{tabular}

Aceh is one of provinces that produce coffee in Indonesia. According to the data published by Directorate General of Estate Crops, in 2015 Aceh produce 47.444 tons of coffee. It account for 7, 88\% of Indonesia coffee production. 88,13\% of the total coffee production in Aceh is Arabica Coffee. It contributes to 25,96\% of Indonesia's Arabica Coffee export.

While Arabica Arabica Coffee mostly grows in District Aceh Tengah and Bener Meriah, Robusta Coffee widespreadly.According the official report by Secretariate General of Estate Crops ccoffeeplantations in Aceh Jaya are run by 2,125 families covering total area of 1,561 acres. Hence, each family manages around 0.74 hectars of land. Until 2015, productive area was 524 hectars, with a total production of 245 tons annually, or an average production of 0.468 ton per hectars [3].

Compared to the national production average of Robusta coffee, the production rate of Lamno's Robusta coffee is relatively low. The unintensive farming system might be the reason behind the low of production. The farmers do not use fertilizers and rely mostly on natural fertility of soil. Moreover, they do not prune and trim the plants regularly. The farmers also do not use an appropriate irrigation system for the plantation.

Regardless its small share in the national coffee market, Lamno Robusta coffee has played a key role in the local market for the last 70 years. Moreover, Lamno Robusta coffee has all the potentials to be developed further.For this reason, extensive and further study is needed with regards to the industry and strategic analysis of Lamno Robusta Coffee.

\subsection{Problem Statement}

This reseach will be conducted to uncover the following problems: (1) how strong the competitive forces of Lamno Robusta Coffee; (2) how are the internal and external factor that influence the Lamno Robusta Coffee Farming; and (3) how are the industry attractiveness and the business strenght the Lamno Robusta Coffee Farming.

\section{Literature Review}

\subsection{Industry analysis}

Economists define an industry as a group of firms that supplies a market [4]. To understand the competitive dynamics of an industry, businesses and analysts use industry analysis as a market assessment tool [5].The objective of industry analysis is to indentify the factors that determine the level of profit in an industry [4]. According to Porter the industry analysis is needed to underpinning of competition and the root causes profitability[6]. Hence, agood industry analysis will uncover which forces that are underpinning (or constraining) today's profitability and how might shifts in one competitive force trigger reactions in others [6].

The understanding the competitive forces, and their underlying causes, reveals the roots of an industry's current profitability while providing a framework for anticipating and influencing competition and profitability over time [6]. Moreover, the understanding of the market forces will give an insight for related parties to design a strategy in order to anticipate as well as to influence the competition in the market.

There are five basic forces that influences the state of competition in an industry which are threat of the new entrants, threat of substitute products, bargaining power of suppliers, bargaining power of buyers and the rivalry among the competitors [7]. These concept is called Porter's Five Forces. Porter [7] highlighted that knowledge of the competitive forces provides the groundwork for strategic action in order to make sure the sustainability of the profitable business in the long run. Related to the strategic action, Porter (Porter: 1980) suggest that the executive apply the following steps, (1) set the business in the position where the threats are the lowest; (2) take advantage the change in the competitive forces in the industry; dan (3) if it possible change the competitive forces for the good sake of the business. 
The strength of each of these competitive forces is determined by a number of key structural variables [4]. According to Grant [4], these key structural variable are: (1) Threat of New Entrants: capital requirements, economies of scale, absolute cost advantages, product dif ferentiation, access to distribution, legal barriers, retaliation, etc; (2) Threats of Substitute Products: buyers' propensity to substitute, relative prices and performance of substitutes, etc.; (3) Bargaining Power of supplier: buyer price sensitivity, relative bargaining power of buyer, etc; (4) Bargaining Power of Buyer: cost of product relative to total cost, product differentiation, competition between buyers, size and concentration of buyers relative to producers, buyers' switching costs, buyers' information, buyers' ability to backward integrate, etc.; (5) Rivalry Among Competitors: concentration, diversity of competitors, product dif ferentiation, excess capacity and exit barriers, cost conditions, etc.

\subsection{Strategic Analysis}

Strategic analysis is the process of conducting research on a company and its operating environment to formulate a strategy [5]. McKinsey definedstrategy as an integrated set of actions designed to create a sustainable advantage over competitors [8]. There are many tools that are currently available for strategic analysis. Most of them use multy criteria decision analysis (MCDA) techniques such as SWOT Analysis, GE/ McKinsey'snine box matrix, etc. Multi-criteria decision analysis is an umbrella term describing the collection of formal approaches that take explicit account of multiple criteria in order to explore alternative decisions [9]. These strategic analysis tools can be used to get an insight of a diversified company's business units in a way that suggests which units should be kept and which sold off and how financial resources should be allocated among them [8].

SWOT framework classifies the various influences on a firm's strategy into four categories:

Strengths, Weaknesses, Opportunities, and Threats. Strengths and weaknesses are related to the internal environment of the firm, especially its resources and capabilities; while the opportunities and threats are related to the external environment of the firm [4].

GE/McKinsey's s nine-box matrix analyze the business based on two dimensions which are the attractiveness of the relevant industry and the unit's competitive strength within that industry. The matrix devides the business in three groups; (1) the business units below the diagonal of the matrix are the one that perform purely, so it will be the candidates to be sold, liquidated, or to consume littlenew capital; (2) the one on the diagonalcan be candidates for selective investment; (3) and the business units above the diagonal are the one that perform well, so its should pursue strategies of either selective or aggressive investment and growth [8].

\section{Methods And Materials}

\subsection{Research Methods}

This research will apply descriptive qualitative approach using MCDA to solve the above problems. Three MCDA'stechniques will be used. These techniques are: (1) Porter's Five Forces Analysis; (2) Strenghts, Weaknesses, Opportunities and Threats (SWOT) Analysis; and (3) GE/ McKinsey Matrix will be applied subsequently to analyze the internal and external factors as well as the the industry and business attractiveness of Lamno Robusta Coffee. First, Porter's five forces will be used to analyse the competitive forces of the coffee industry. Later, the SWOT framework will be applied to get insight on the internal and external factor that influence the Lamno Robusta Coffee business. The weighted score of the five competitive forces will be assign to measure the threats that shape the external factor of the business. Lastly, the GE/McKinsey Matrix will utilized to have a full description on the strategic position of Lamno Robusta Coffee. The weighted score of the SWOT's external factor will be used to quantify the industry attractiveness, while the weighted score of SWOTS's internal factor will be used to measure the business strength of Lamno Robusta Coffee. 


\subsection{Reseach Framework}

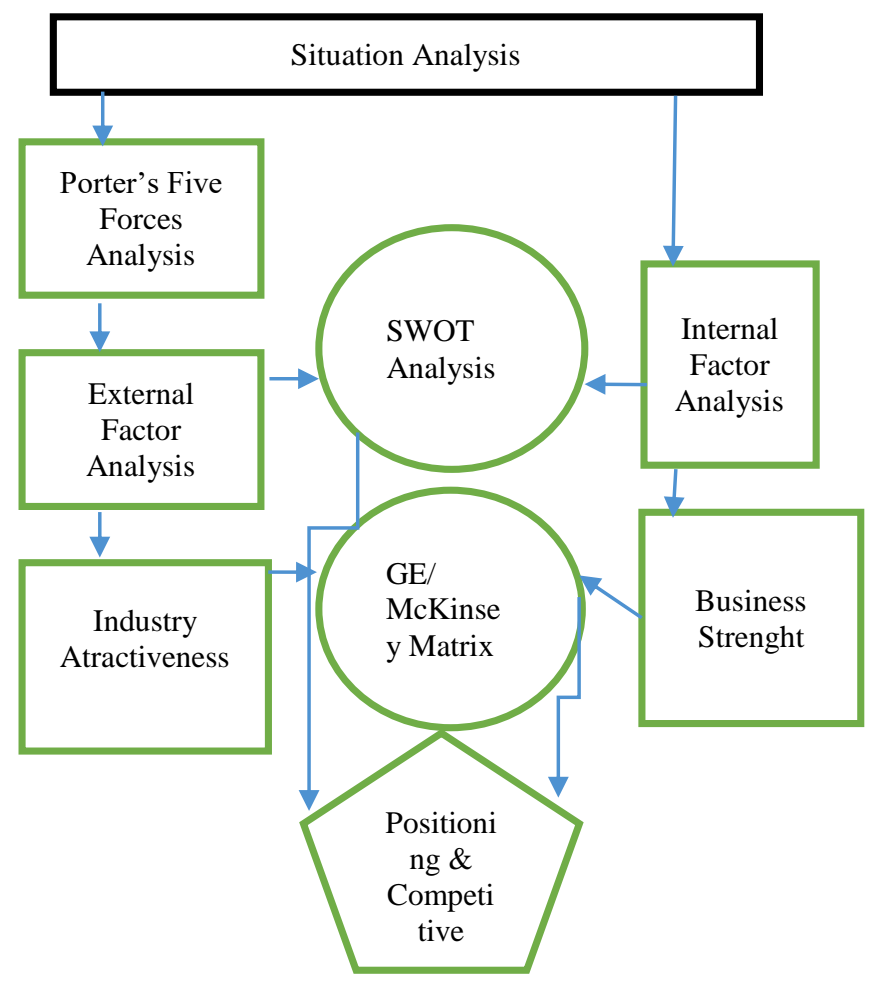

\subsection{Data Collection}

Figure 1. Reseach Framework

The reaseach will used both the primary and secondary data. The primary data will be collected from direct observation in field, conducting interview and focus group discussion (FGD) with the stakeholders including but not limitted to the farmers, the middlemen, the coffee roaters/ brwers, and government officials. While the secondary data will get from credible resources such as the International Coffee Organization (ICO), the United States Department of Agriculture (USDA), Directorate General of Estate Crops, etc.

\section{Result And Discussion}

\subsection{Competitive Forces Analysis}

Porter's Five Forces will be used to analyze the competitive forces related to Lamno Robusta Coffee. Parameters of the five forces will be measured based on the perception of the the farmers, middlemen, the elders of the community, the consumers, the coffee grounders and other related parties. The analysis will be conducted as below:

1. Indentify the relevan variables that affect the competitive forces.

2. Assign a weight that ranges from 0.00 to 1.00 to each variables. The weight assigned to a given variable indicates the relative importance of the variable. 0.00 means not important, while 1.00 indicates very important.

3. Assign a 1 to 5 rating to each variable. The rating captures whether the factor represents a major weakness (rating $=1$ ), a minor weakness (rating $=2$ ), neutral (rating $=3$ ), a minor strength (rating $=4$ ), or a major strength (rating $=5$ ).

4. Multiply each variable's weight by its rating to get the weighted score for each variable.Each competitive force will get into one out of three catagories as the following: 
1) Weakif the weighted score of competitive forces range from 0.00 to 1.67

2) Mediumif the weighted score of competitive forcesrange from 1.68 to 3.34

3) Strongif the weighted score of competitive forcesrange from 3.35-5.00

\subsection{Internal and External Factor Analysis}

Descriptive qualitative analysis will apply to get insight on the internal and external factor that influence the Lamno Robusta Coffee. Internal factor will depends on the strenght and the weakness of the business, while the external factor will be determined by the opportunity and the threat to business. Parameters of each factor will be measured based on the conclusion of field observation and interviews with stakeholders. The internal and eksternal factor analysis will be the base ground for the SWOT Analysis that will reveal the strategic position of the Lamno Robusta Coffee.

The internal factor analysis will be conducted as below:

1 Identify 10 variable that determine the strenght and weakness of the Lamno Robusta Coffee

2 Assign a weight that ranges from 0.00 to 1.00 to each variables. The weight assigned to a given variable indicates the relative importance of the variable. 0.00 means not important, while 1.00 indicates very important.

3 Assign a 1 to 5 rating to each variable. The rating captures whether the factor represents a major weakness (rating $=1)$, a minor weakness (rating $=2$ ), neutral (rating $=3$ ), a minor strength $($ rating $=4)$, or a major strength (rating $=5$ ).

4 Multiply each variable's weight by its rating to get the weighted score for each variable.

The external factor analysis will follow the following rules:

1 Identify 10 variable that determine the opportunities and threats of the Lamno Robusta Coffee

2 Assign a weight that ranges from 0.00 to 1.00 to each variables. The weight assigned to a given variable indicates the relative importance of the variable. 0.00 means not important, while 1.00 indicates very important.

3 Assign a 1 to 5 rating to each variable. The rating captures whether the factor represents a major opportunity (rating $=1$ ), a minor opportunity (rating $=2$ ), neutral (rating $=3$ ), a minor threat $($ rating $=$ 4 ), or a major threat (rating $=5$ ).

4 Multiply each variable's weight by its rating to get the weighted score for each variable.

Based on the weighted score of internal and external factor analysis, the strategic positioning of Lamno Robusta Coffee can be identified by conducting SWOT Analysis. The criteria for strategy formulation are below:

(1) Strategy SO; the weighted score for external factor ranges 2.5-5 and the weighted score for internal factor ranges 2.5-5.0

(2) Strategi ST; the weighted score for external factor ranges $0.0-2.5$ and the weighted score for internal factor ranges $0.0-2.5$

(3) Strategi WT; the weighted score for external factor ranges $0.0-2.5$ and the weighted score for internal factor ranges $0.0-2.5$

(4) Strategi WO; the weighted score for external factor ranges 2,5-5 and the weighted score for internal factor ranges $0.0-2.5$

\subsection{Industry Attractiveness}

GE/McKinsey Matrix will be applied to get insight on industry atractiveness and business strengt of Lamno Robusta Coffee. The industry atractiveness can be indentified from the wighted score of external factor analysis, while the wighted score of intenal factor analysis will show the business strenght of Lamno Robusta Coffee. The internal factor will get into one out of three catagories as the following:

1. Weak if the weighted score of internal factor range from 0.00 to 1.67

2. Medium if the weighted score of internal factor range from 1.68 to 3.34

3. Strong if the weighted score of internal factor range from $3.35-5.00$

The Graph below shows the GE/ McKinsey Matrix Analysis: 
Table 2. GE/ McKenseyMatrix

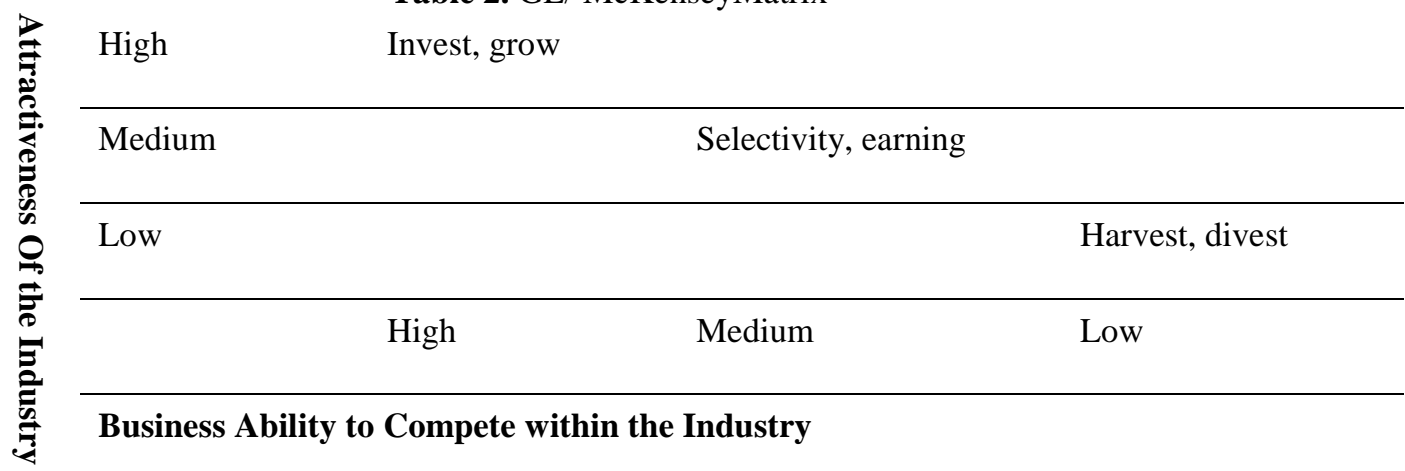

Resources: Gluck et al. (2000)

\section{Discussion}

Based on the field observation, the coffee is currently cultivated mostly in 3 villages in Jaya Sub Distric which are Pantee Cermin, Sabeet and Mareue. Based on our survey to 64 families who are living in those villages, 93,33\% of the families owned coffee plantatation. In average the farmers manage 1.12 hectars coffee of land. Most of the farmers inherit their farming from their parent. The age average of the farmers are 45 years old with 11 years of experience in coffee farming. The farmers applied multi crops farming method.

The survey reveals that the age average of the plants are 9.98 years with the average amount of production is as much as $214.61 \mathrm{~kg}$ per hectar. The survey also shows the current total area of the robusta coffee farming in Aceh Jaya is 650 hectars. Therefore, the total coffee production in Aceh Jaya is predicted to be 139.50 ton. This amount is equal to $0.02 \%$ of total coffee production in Indonesia.

Based on the focus group discussion conducted with the middlemen and the elders from 3 villages that produce coffee in Jaya Sub Distric, the amount of coffee production in Aceh Jaya has been decreased to be less than half ot its peak production before the turning of the centuries. The militery conflict and the tsunami were two events that garnered the decrease of the coffee production in Aceh Jaya. Most farmers leaved their farming for years because of the conflict. Before the security condition was stable, the tsunami hit the surrounded area in 2004. The tsunami that brought a temporary micro climate change had devastated the coffee farming around the coastal area. Three vilages that mentioned above saved from the micro climate change because of their location are far from the costal area.

According to the elders most of the farmers do not have enough knowledge for coffee cultivation. The farmers have never applied fertilizer to their coffee plants. The fertility of the soil is the sole resource of nutrient supplies for their farm. They also do not prune their plants regularly. On the top of that the farmers used herbicide that make the soil become degraded to killl the unwanted plants. All of those have contributed to the going decrease of coffee production in Aceh Jaya.

Contradicted to the decrease of production, the demand for Lamno Robusta Coffee persistently increase for the last few years. The increase of income and population has affected to the demand for coffee in Aceh. The local coffee roasters such as CV. Tgk. Aceh, CV. Solong Premium Coffee Ulee Kareng, CV. Solong Coffee Ulee Kareng and a few other coffee roasters have used Lamno Robusta Coffee green beans as their main raw material for their product for a long time.

Mr. Hasballah, the owner of Solong Premium Coffee Kareeng, reveals that the taste of Lamno Robusta Coffee is the best one. Moreover, because of its special taste, Mr. Hasballah who inherite the business from his father consistently use Lamno Robusta Coffee to produce his product. Unfortunately because of the limitted production he has to mix the Lamno Robusta Coffee with other robusta coffee.

The increase of the demand that is not supported by the increase of supply combine with the local roasters preference, has make the price of the Lamno Robusta Coffee going up. In 2018 the price of the Lamno Robusta Coffee is $\$ 3.00 / \mathrm{kg}$. It higher than the price of the robusta coffee in the world market that is traded at $\$ 2.25 / \mathrm{kg}$ in 2018. 


\subsection{Competitive Forces of Lamno Robusta Coffee}

The strength of each comptitive forces will be measured using structural variables as suggest by Grant (2016). The weighted and rating for each variable are the results from the combination of secondary data, FGD, and dept interviews with the stakeholders.

\subsection{Threats of New Entrants}

The threats of the new entrants will be analyzedusing five relevan variables which are capital requirements, consumer's loyalty, economies of scale, access to distribution channel, and legal barriers.

Table 3. The Threat of The New Entrants Analysis

\begin{tabular}{|c|c|c|c|c|c|c|}
\hline No. & Indicator & Analysis & Weight & Rating. & Score & Conclusion \\
\hline 1 & $\begin{array}{l}\text { Capital } \\
\text { requirement }\end{array}$ & $\begin{array}{l}\text { Capital requirement relatively low. Our survey } \\
\text { shows that the average initial investment per } \\
\text { hectar for Lamno Robusta Coffee farming is Rp. } \\
22.335 .000 \text {. }\end{array}$ & 0.30 & 5.00 & 1.50 & \multirow[t]{6}{*}{$\begin{array}{l}\text { The threat of the new entrants is } \\
\text { strong withthe weighted score } \\
\text { range between } 3.35-5.00\end{array}$} \\
\hline 2 & $\begin{array}{l}\text { Consumer's } \\
\text { loyality }\end{array}$ & $\begin{array}{l}\text { Because of its special taste Lamno Robusta } \\
\text { Coffee almost cannot replace by the other coffee } \\
\text { product. }\end{array}$ & 0.30 & 1.00 & 0.30 & \\
\hline 3 & $\begin{array}{l}\text { Access to } \\
\text { the } \\
\text { distribution } \\
\text { channel }\end{array}$ & $\begin{array}{l}\text { Access to the distribution channel is relatively } \\
\text { easy because the coffee market have been existed } \\
\text { for decades in Aceh }\end{array}$ & 0.20 & 4.00 & 0.80 & \\
\hline 4 & $\begin{array}{l}\text { The } \\
\text { economies } \\
\text { of scale }\end{array}$ & $\begin{array}{l}\text { The economies of scale is relatively low. The } \\
\text { farmers can start a profitable farming for less than } \\
\text { one hectar of land. }\end{array}$ & 0.10 & 5.00 & 0.50 & \\
\hline 5 & $\begin{array}{l}\text { Legal } \\
\text { barriers }\end{array}$ & $\begin{array}{l}\text { There are no legal barrier to start a coffee farming } \\
\text { in Aceh or Indonesia. }\end{array}$ & 0.10 & 5.00 & 0.50 & \\
\hline Tot & core & & 1.00 & & 3.60 & \\
\hline
\end{tabular}

Source: Survey Data

The above Graph shows that out of five variables that determine the threats of the new entrants, only one variable which is consumer's loyalty that have a low rating. This contribute to the strong forces of the new entrants.

\subsection{Threats of Substitute Products}

Five variables that determine the threat of the substitute products are: buyers' propensity to substitute, the accessibility of the substitute products, relative prices, switching cost and the service performance of the substitutes products.

\begin{tabular}{|c|c|c|c|c|c|c|}
\hline No. & Indicator & Analysis & Weight & Rating. & Score & Conclusion \\
\hline 1 & $\begin{array}{l}\text { Buyers' propensity to } \\
\text { substitute }\end{array}$ & $\begin{array}{l}\text { There are many } \\
\text { substitution product for } \\
\text { coffee in Aceh such tea, } \\
\text { juices, etc. However, } \\
\text { for coffee lover, all of } \\
\text { these substitute product } \\
\text { cannot fully replace } \\
\text { coffee }\end{array}$ & 0.20 & 2.50 & 0.20 & $\begin{array}{l}\text { The threat of the substitute } \\
\text { products is mediumwith the } \\
\text { weighted score range } \\
\text { between1.67-3.35 }\end{array}$ \\
\hline 2 & $\begin{array}{l}\text { The accessibility of the } \\
\text { substitute products }\end{array}$ & $\begin{array}{l}\text { Every consumers can } \\
\text { get any substitute } \\
\text { product easily in Aceh }\end{array}$ & 0.20 & 4.00 & 0.80 & \\
\hline 3 & Relative prices & $\begin{array}{ll}\text { The price of } & \text { substitute } \\
\text { products } & \text { relatively } \\
\text { competitive. } & \end{array}$ & 0.20 & 3.00 & 0.60 & \\
\hline
\end{tabular}




\begin{tabular}{|c|c|c|c|c|c|}
\hline 4 & Switching cost & $\begin{array}{l}\text { Because of its specific } \\
\text { fuction (e.g to stay } \\
\text { awake at night), the one } \\
\text { who one to replace } \\
\text { coffee with other } \\
\text { brevarage need spend } \\
\text { extra money }\end{array}$ & 0.20 & 1.00 & 0.20 \\
\hline 5 & $\begin{array}{l}\text { The service performance } \\
\text { of substitute products }\end{array}$ & $\begin{array}{l}\text { The service } \\
\text { performance of } \\
\text { substitute product } \\
\text { relatively the same }\end{array}$ & 0.20 & 3.00 & 0.60 \\
\hline
\end{tabular}

\section{Source: Survey Data}

The above Graph shows that out of five variables that determine the threats of substitute products, only the accessibility of the substitute products that have a relatively high rating. Moreover, because of the consumers might have to spends extra money to replace coffee with a few substitute products, the rating for the switching cost become relatively low that weaker the forces of substitutes products.

\subsection{Bargaining Power of Buyers}

There five variables that determinethe bargaining power of buyers. These variables are; the product' standard, competition between buyers, the amount of supply, concentration of buyers relative to producers, and buyers' information.

Table 5. Bargaining Power of Buyers

\begin{tabular}{|c|c|c|c|c|c|c|}
\hline No. & Indicator & Analysis & Weight & Rating. & Score & Conclusion \\
\hline 1 & $\begin{array}{l}\text { Concentration of } \\
\text { buyers relative } \\
\text { to producers, }\end{array}$ & $\begin{array}{l}\text { More than } 60 \% \text { of Lamno Robusta Coffee bought by } \\
\text { three } 3 \text { companies that produce grounded coffee in } \\
\text { Banda Aceh }\end{array}$ & 0.20 & 4.00 & 0.80 & \multirow{6}{*}{$\begin{array}{l}\text { The bargaining } \\
\text { position of buyers } \\
\text { considered medium } \\
\text { with the weighted } \\
\text { score range } \\
\text { between1.67-3.35 }\end{array}$} \\
\hline 2 & $\begin{array}{l}\text { Competition } \\
\text { between buyers }\end{array}$ & $\begin{array}{l}\text { Competition between buyers considerd high. The } \\
\text { entrant of the new players in the coffee processing } \\
\text { business have create competition betweeen buyers of } \\
\text { Lamno Robusta Coffee. Three old buyers that } \\
\text { dominate the market cannot control the new player } \\
\text { who come into the market by offering the higher } \\
\text { price. At the same time the old player who have } \\
\text { acknowledge the special taste of Lamno Robusta } \\
\text { Coffee and do not want the taste of their coffee } \\
\text { product change, cannot replace the Lamno Robusta } \\
\text { Coffee with other robusta simply because of the } \\
\text { price. Hence, it make the price of Lamno Robusta } \\
\text { Coffee higher than the world market price. }\end{array}$ & 0.20 & 2.50 & 0.50 & \\
\hline 3 & $\begin{array}{l}\text { The amount of } \\
\text { supply }\end{array}$ & $\begin{array}{l}\text { The amount of Lamno Robusta Coffee production } \\
\text { relatively small compared to demand for coffee in } \\
\text { Aceh. It is can only supply less than } 1 \% \text { coffee for the } \\
\text { local market. }\end{array}$ & 0.40 & 1.00 & 0.40 & \\
\hline 4 & $\begin{array}{l}\text { The standard of } \\
\text { product }\end{array}$ & $\begin{array}{l}\text { The buyers do not set a specific standard for the } \\
\text { Lamno Robusta Coffee. They are willing to pay the } \\
\text { same price for the different grade of Lamno Robusta } \\
\text { grean bean. }\end{array}$ & 0.10 & 1.00 & 0.10 & \\
\hline 5 & $\begin{array}{l}\text { Buyers' } \\
\text { information. }\end{array}$ & $\begin{array}{l}\text { The buyers have a good access to the market } \\
\text { information. }\end{array}$ & 0.10 & 4.00 & 0.40 & \\
\hline Tota & & & 1.00 & & 2.20 & \\
\hline
\end{tabular}

Source: Survey Data 
The above analysis shows that although the concentration of buyers relative high, the limitted supply make the buyers do not have enough bargaining power in determine the price of the green bean. The buyers even cannot set a standard quality for the coffee they bought. All of thiese facts lead to the medium force from the buyers.

\subsection{Bargaining Power of Supplier}

The bargaining power of buyers influence by 5 variables which are; concentration of suppliers relative to buyers, the dependency of supplier to particular industry, switching cost of buyers, substitution of product provided by supplier, and supplier threaten to integrate forward into the industry.

Table 6. Bargaining Power of Suppliers

\begin{tabular}{|c|c|c|c|c|c|c|}
\hline No. & Indicator & Analysis & Weight & Rating. & Score & Conclusion \\
\hline 1 & $\begin{array}{l}\text { Concentration of } \\
\text { suppliers relative } \\
\text { to buyers }\end{array}$ & $\begin{array}{l}\text { The Lamno Robusta Coffee farming managed } \\
\text { traditionally. Most of the material for the coffee } \\
\text { farming fullfil by the farmer themself. The farmer } \\
\text { only need a few farming tools such as cutting } \\
\text { mechine from suppliers. There are anumber of } \\
\text { supplier who provide that tools. The level of } \\
\text { competition between supplier considered high } \\
\text { because of the limitted market. }\end{array}$ & 0.20 & 2,50 & 0.50 & $\begin{array}{l}\text { The bargaining } \\
\text { position of suppliers } \\
\text { considered lowwith } \\
\text { the weighted score } \\
\text { range between } 0.00 \text { - } \\
1.67 \text {. }\end{array}$ \\
\hline 2 & $\begin{array}{l}\text { Substitution of } \\
\text { product provided } \\
\text { by supplier }\end{array}$ & $\begin{array}{l}\text { The farmer have many alternative for the product } \\
\text { provided by supplier. }\end{array}$ & 0.25 & 1.00 & 0.20 & \\
\hline 3 & Switching cost & $\begin{array}{l}\text { The farmer do not have to spend additional cost if } \\
\text { they switch supplier }\end{array}$ & 0.20 & 1.00 & 0.20 & \\
\hline 4 & $\begin{array}{l}\text { The dependency } \\
\text { of supplier to } \\
\text { particular industry }\end{array}$ & $\begin{array}{l}\text { The revenue of the supplier do not depend on the } \\
\text { purchasing of their product by the coffee farmer. } \\
\text { They can sell the related product to the other } \\
\text { group of buyers. }\end{array}$ & 0.20 & 2,50 & 0.50 & \\
\hline 5 & $\begin{array}{l}\text { Supplier threaten } \\
\text { to } \quad \text { integrate } \\
\text { forward into the } \\
\text { industry }\end{array}$ & $\begin{array}{l}\text { The suppliers do not have enough reason to enter } \\
\text { the coffee farming simply to increase their } \\
\text { bargaining position to the farmers }\end{array}$ & 0.20 & 1.00 & 0.20 & \\
\hline Tota & Score & & 1.00 & & 1.60 & \\
\hline
\end{tabular}

\section{Source: Survey Data}

The bargaining power of supplier is considered low because the Lamno Robusta Coffee farming is managed traditionally by the farmers and most of the material for the farming including but not limitted to seed and man power are provided by the farmer themself.

\subsection{Rivalry Among The Existing Competitors}

The intensity of rivalry will be measured using five variable as follow: number of competitors, product differentiation, the industry growth, exit barriers, business commitment.

\begin{tabular}{|c|c|c|c|c|c|c|}
\hline No. & Indicator & Analysis & Weight & Rating. & Score & Conclusion \\
\hline 1 & $\begin{array}{l}\text { The industry } \\
\text { growth }\end{array}$ & $\begin{array}{l}\text { The world growth of coffee consumption in was } \\
1,3 \% \text { latley, however it will be increase in the } \\
\text { near future along with the increase of the coffee } \\
\text { consumption in emerging market such China. In } \\
\text { national level, the industry growth is supported } \\
\text { by the high growth of consumption that reach } \\
12,15 \% \text { for the last } 7 \text { years. }\end{array}$ & 0.30 & 1.00 & 0.30 & $\begin{array}{l}\text { The intensity of rivalry } \\
\text { among the existing } \\
\text { competitors is medium } \\
\text { with the weighted score } \\
\text { range between } 1.67-3.34\end{array}$ \\
\hline 2 & $\begin{array}{l}\text { Number of } \\
\text { competitors }\end{array}$ & $\begin{array}{l}\text { There are many coffee farming that currently } \\
\text { exist either in Indonesia. Most of the coffee } \\
\text { farming manage in a small scale by hundred }\end{array}$ & 0.20 & 5.00 & 1.00 & \\
\hline
\end{tabular}


thousands of families. In Aceh the coffee farming dominantly take place in Gayo Highland that poduce Arabica Coffee, while robusta coffee are produced in other area.

\begin{tabular}{|c|c|c|c|c|c|}
\hline 3 & $\begin{array}{l}\text { Product } \\
\text { Differentiation }\end{array}$ & $\begin{array}{l}\text { Particular geographical climates would produce } \\
\text { coffee with special aroma and taste (Ponte: } \\
\text { 2001). The special aroma and taste enable Lamno } \\
\text { Coffee to differenciate their product from the rest } \\
\text { of other coffee product that currently exist in the } \\
\text { market }\end{array}$ & 0.20 & 1.00 & 0.20 \\
\hline 4 & $\begin{array}{l}\text { Business } \\
\text { Commitment }\end{array}$ & $\begin{array}{l}\text { Coffee farming that mostly develop in the } \\
\text { developping country mostly manage from } \\
\text { generation to generation. I create a high business } \\
\text { commitment that make the farmer will keep their } \\
\text { farming even in the worst situation. }\end{array}$ & 0.20 & 3.00 & 0.60 \\
\hline 5 & Exit Barrier & $\begin{array}{l}\text { The capital investment for coffee farming is low } \\
\text { and the farmer can replace coffee with other } \\
\text { crops easily. It make the exit barrier low for the } \\
\text { industry }\end{array}$ & 0.20 & 2.00 & 0.40 \\
\hline \multicolumn{2}{|c|}{ Nilai Total } & & 1.00 & & 2.50 \\
\hline
\end{tabular}

\section{Source: Survey Data}

The growth of industry play a dominant role in shaping the strength of rivalry in coffee industry. Although there are many competitors in the industry, the rivalry among the exixting copetitors can be neutralized by highgrowth of industry.

\subsection{The Internal and External Factor Analysis}

Internal Factor Analysis

The internal factor determine by the strenght and weakness of the Lamno Robusta Cofee farming. Each of variable is influenced by five underlying parameters as the following:

1) Strenght

1) Farming Experience;

Most of the farmer inherite their coffe farming from their parent. The survey shows that the average age of the farmers are 46 years with 11 years experience in coffee farming.

2) The Uniqueness of Taste;

The taste of Lamno Robusta Cafee is unique and special that make the coffee processing business owner cannot replace it with the other variety coffee.

3) Specialty coffee branding;

The aplication of organic farming system in a small scale with high intensity of labor enable the coffee farmer to get a premium price by getting organic product certificate or fair trade certificate [10]. Lamno Robusta coffee have a big potential to apply for these two scheme. It because the farmers develop coffee farming with organic system in a small scale. The farmer also develop multy crops farming in which they are not only grow coffee but also other plants for shading.

4) The customer's loyalty

The Lamno Robusta coffee have dominate the local market for 70 years. The existing customers cannot replace the Lamno Robusta green bean because of its special taste.

5) The existing of the market and distribution channel ;

The coffee market has been exist for centuries in Aceh. Hence, the market and distribution channel has been established for a long time.

2) Weakness

1) The farming system;

Lamno Robusta coffee farmers do not implement modern farming system in coffee cultivation. Farmers do not use fertilizer at all in the early stages of planting or when the coffee stalks have started to produce. Farmers also rarely do pruning or weeding regularly. Likewise with irrigation which only depends on the presence of rainwater. This makes coffee production relatively low compared to modern agriculture in other regions. 
2) The economies of scale;

Based on the survey results, the average area of coffee planted by farmers is 1.14 hectares. The economic scale of the farming is relatively low that make it become not really effecient in term of business.

3) Weak marketing practice;

Although the Lamno Robusta coffee has a distinctive taste with organic farming system, it is only known locally. The branding of Lamno Robusta coffee as a special coffee product has never been done.

4) Do not enough knowledge on good farming practice;

Based on the results of the FGD with the farmers and elders of the Lamno community, farmers generally do not have enough knowledge regarding the good practice of coffee cultivation. Farmers only develop coffee cultivation based on the habits of their parents and ancestors.

5) The financing access is limitted;

Based on the information conveyed by the farmers, they generally lack capital in developing agricultural businesses so that the business is carried out with the existing capabilities. Access to banking is very limited. The irregularity of their income and unbankable asset are two main prome that limitted their access to financing resources.

The following table shows the results of internal factor analysis based on the results of in-depth interviews with stakeholders, literature studies and field observation:

Table 8. Internal Factor Analysis

\begin{tabular}{llrrr} 
No & Internal Factor Analysis & Weight & Rank & value \\
\hline & Strength & 0.10 & 3.00 & 0.30 \\
\hline 1 & The farming experience & 0.15 & 4.50 & 0.68 \\
\hline 2 & The uniqueness of taste & 0.15 & 4.00 & 0.60 \\
\hline 3 & Specialty coffee branding & 0.05 & 4.00 & 0.20 \\
\hline 4 & Familiarity in the local market & 0.05 & 4.00 & 0.20 \\
\hline 5 & Market and distribution channel & 0.50 & & 1.98 \\
\hline Sub Total & & & \\
\hline$\quad$ Weakness & 0.15 & 1.00 & 0.15 \\
\hline 1 & The farming system & 0.10 & 2.00 & 0.20 \\
\hline 2 & The economies of scale & 0.05 & 2.00 & 0.10 \\
\hline 3 & Weak marketing practice & 0.10 & 1.00 & 0.10 \\
\hline 4 & Limited knowledge on good farming practice & 0.10 & 1.00 & 0.10 \\
\hline 5 & Financial access & 0.50 & & 0.65 \\
\hline Sub Total & 1.00 & 2.63
\end{tabular}

Source: Survey Data

The result of internal factor analysis shows that the strenght of Lamno Robusta Coffee farming overcome its weakness.

2. Internal Factor Analysisa

1) Opportunities

1) The industry growth;

The industry growth was high in the national level. It was supported by the high growth of coffee consumtion that reach $12,15 \%$ annual grwth for the last 7 years. The data from the International Coffee Organization (ICO) shows that the growth average of coffee consumption was 1,3\% for the last five years. Moreover ICO stated that the emerging market country will be the driver of the world coffee demand [2].

2) The market size;

The United States Department of Agriculture (USDA), the world coffee consumption is projected to reach 9.792.000 ton in 2018. The same rosource conveyed that the Indonesian coffee consumption in 2018 is predicted around 213.600 ton. Our survey suggest that the coffee consumption in Aceh reach 36.485 ton in 2017. These facts show that the market size of coffee product relatively big compared to capacity production of Lamno Robusta Coffee.

3) The fair trade practice; 
Advocacy from environmental activists and human rights related to environmental sustainability and income distribution as well as fair trade practice during the past few decades have begun fruitfull with the emergence of special coffee certification and fair trade implementation. This becomes more real when accompanied by the willingness of consumers to buy the specialty coffee products.

4) The economic growth;

The eeconomic growth of Indonesia consistently above 5\% per year for the last five years. It has contributed to the increasing of income per capita. Consequently, it increase the purchasing power of the community that encouraged the coffee consumption.

5) The government support;

The Government has provided sufficient support for the development of coffee farming businesses including promoting coffee product and direct assistance to the farmers. For Lamno Robusta coffee farmers, the Regency and Provincial Governments have provided assistance in term of land certification and seed assistance

\section{2) Threats}

The are five underlying variables that potentially become the threat for the Lamno Robusta coffee farming as has been explain in the above. These variables are; threat of the new entry, threat of substitution products, the rivalry among the existing competitors, the bargaining power of buyers and the bargaining power of suppliers.

The following table shows the results of external factor analysis based on the results of in-depth interviews with stakeholders, literature studies and field observation:

Table 9. External Factor Analysis

\begin{tabular}{llrrr} 
No & External Factor & Weight & Rank & value \\
\hline & Opportunities & & & \\
\hline 1 & The industry growth & 0.15 & 3.00 & 0.45 \\
\hline 2 & The market size & 0.15 & 4.50 & 0.68 \\
\hline 3 & The fair trade practice & 0.05 & 2.50 & 0.13 \\
\hline 4 & The economic growth & 0.10 & 2.75 & 0.28 \\
\hline 5 & The government support & 0.05 & 2.50 & 0.13 \\
\hline Sub Total & Threats & 0.50 & & 1.65 \\
\hline$\quad$ Threat of the new entry & & & \\
\hline 1 & Threat of substitution products & 0.10 & 3,6 & 0.36 \\
\hline 2 & The rivalry among the existing competitors & 0.10 & 2,4 & 0.24 \\
\hline 3 & The bargaining power of buyers & 0.05 & 0.13 \\
\hline 4 & The bargaining power of suppliers & 0.15 & 2,5 & 0.33 \\
\hline 5 & 2,2 & 0.16 \\
\hline Sub Total & 0.10 & 1,6 & 1.22 \\
\hline Total Score & 0.50 & & 2.87
\end{tabular}

\section{Sumber: Survey Data}

The result of external factor analysis shows that the opportunities of Lamno Robusta Coffee farming overcome its threats. The following graph shows the SWOT Analysis based on the internal and external factor analysis above. 
Figure 2. SWOT Analysis of Lamno Robusta Coffee

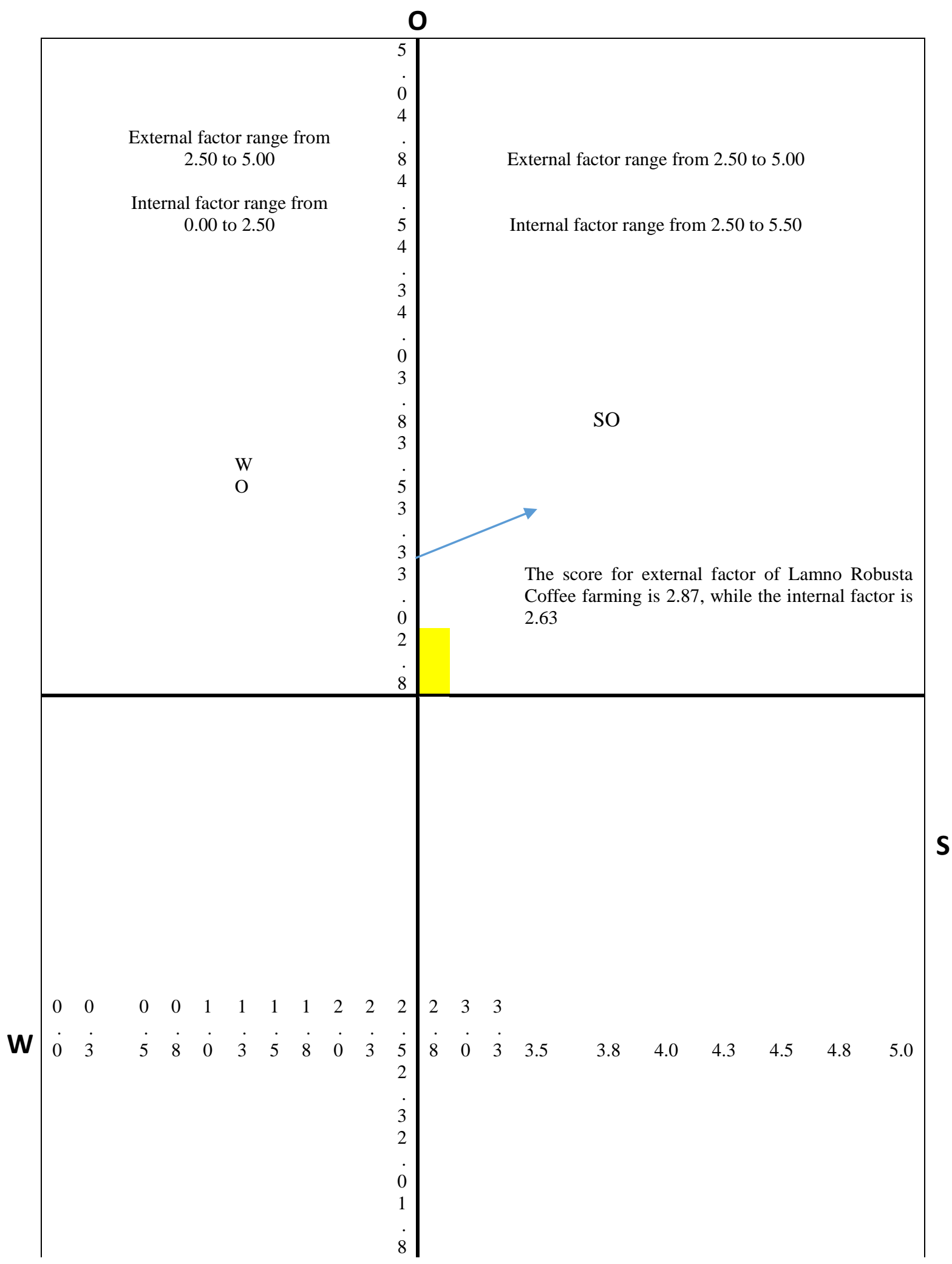




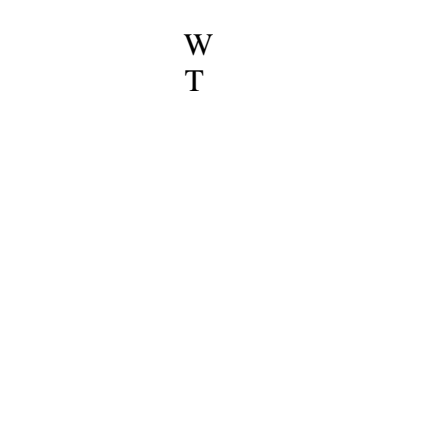

External factor range from 0.00 to 2.50

Internal factor range from 0.00 to 2.50
ST

External factor range from 0.00 to 2.50

Internal factor range from 2.50 to 5.00

$\mathbf{T}$

Both the total weighted score ofthe internal factor and the external factor that influence the business of Lamno Robusta coffee are more than 2.50. It is mean that the strength of the business overcome its weakness, while the opportunities the business might have overcome the threats it might face.

\subsection{Industry Atractiveness and Business Stenght Analysis}

The internal and internal factor analysis inline with the industry atractiveness and business analysis. Because the external factor represented the industry attractiveness, while the internal factor represent the business strenght. The GE/McKinsey Matrix of Lamno Robusta Coffee is formed based on the above assumption.

Since the score for industry attractiveness is 2.87 , while the business strenght is 2.63 , the Lamno Robusta Coffee Farming will be placed in cell $\mathrm{E}$ of GE/McKinsey Matrix. It mean that both the market attractiveness and the business strenght are in medium position. Therefore the farmer have to focus on the core business and invest more on production to achieve ecomies of scale as well as marketing to create brand image in order to get a better position.

Table 10. GE/ McKinsey Matrix of Lamno Robusta Coffee Farming

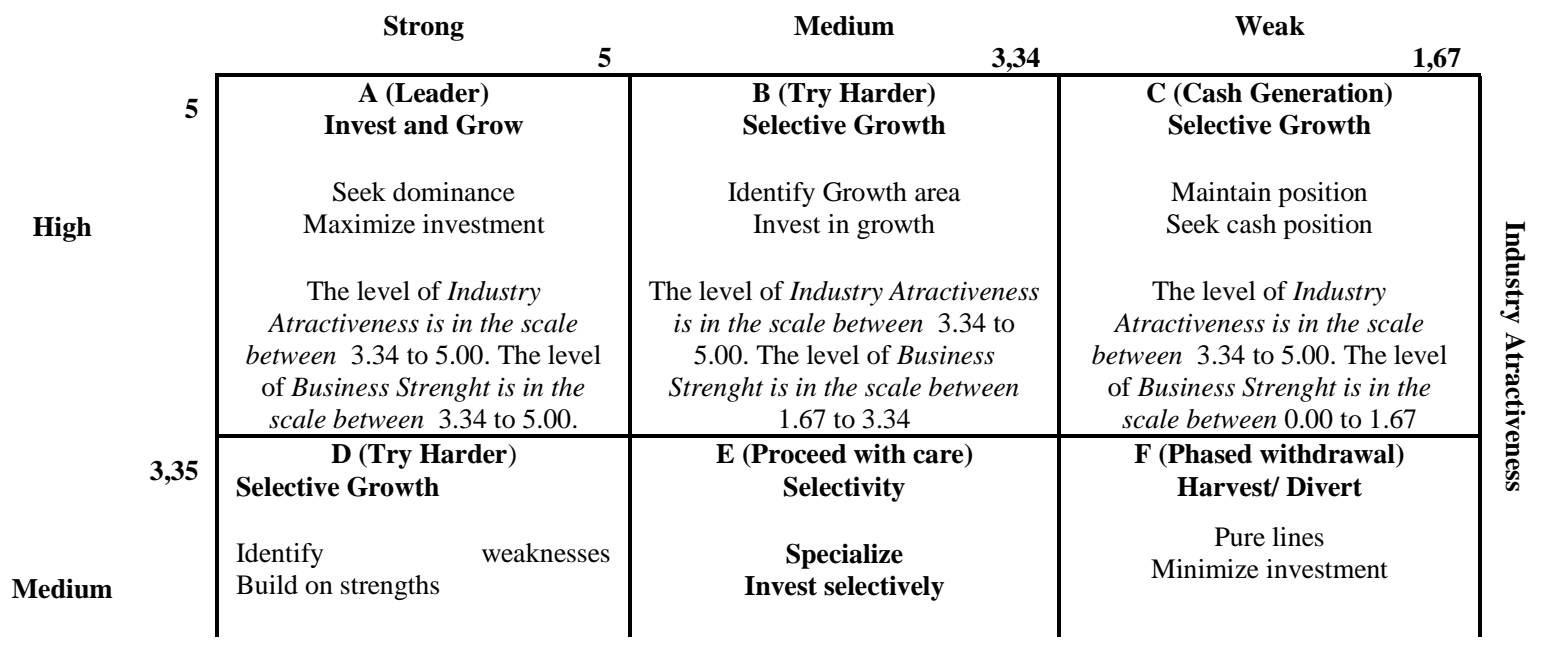




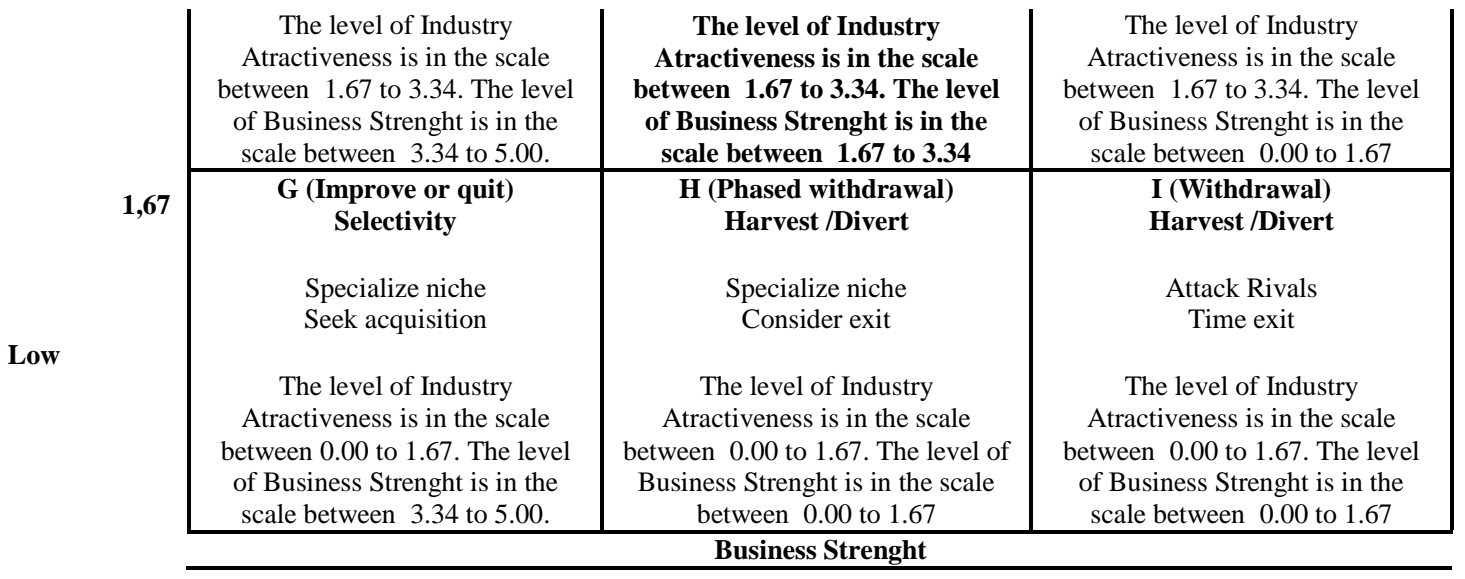

Sources: Adaptation from Mokaya (2012) based on Mann \& McKinsey and Company (1971)

\section{REFERENCE}

[1] USDA, "Coffee: World markets and trade," United States Department of Agriculture Foreign. Foreign Agricultural Service, 2018. .

[2] ICO, "Coffee market continues downward trend," London, 2018.

[3] _ Direktorat Jenderal Perkebunan, Statistik perkebunan Indonesia 2015-2017 kelapa sawit. Jakarta: Sekretariat Direktorat Jenderal Perkebunan, Direktorat Jenderal Perkebunan, Kementerian Pertanian, 2016.

[4] R. M. Grant, Contemporary strategy analysis: Text and cases, 9th ed. West Sussex, UK: John Wiley \& Sons, 2016.

[5] CFI, "Strategic Analysis," Corporate Finance Institute, 2018.

[6] M. E. Porter, "The five competitive forces that shape strategy," Harv. Bus. Rev., vol. 86, no. 1, pp. 7893, 2008.

[7] M. E. Porter, How competitive forces shape strategy. Boston: Harvard Business Review, 1979.

[8] F. W. Gluck, S. P. Kaufman, A. S. Walleck, K. McLeod, and J. Stuckey, "Thinking strategically," McKinsey Quarterly, Strateg. Anthol., no. Spring, 2000.

[9] M. Tsakalerou, A meta-study of intellectual capital and firm performance: When the whole is more than the sum of its parts, vol. 12. 2015.

[10] A. Murekezi, Profitability analysis and strategic planning of coffee processing and marketing in Rwanda: A case study of a coffee growers' association. 2003.

[11] S. Mokaya, "Corporate entrepreneurship and organizational performance Theoretical perspectives, approach and outcomes," Int. Jorunal Arts Commer., vol. 1, no. 4, pp. 133-143, 2012.

[12] R. Mann and McKinsey and Company, The arts of top management: A McKinsey anthology. New York: McGraw-Hill, 1971. 
